\title{
高度变形性膝関節症に対する脛骨顆外反骨切り術の治療成績
}

\author{
佐世保市立総合病院整形外科 \\ 宮 本 俊之・宮原健 次 \\ 牧野佳明・杉谷勇二
}

\section{Clinical Results of Tibial Condyle Valgus Osteotomy for Severe Osteoarthritis of the Knee}

\author{
Takashi Miyamoto, Kenji Miyahara, Yoshiaki Makino, \\ and Yuji Sugitani \\ Department of Orthopedic Surgery Sasebo \\ City General Hospital, Nagasaki, Japan
}

\begin{abstract}
We evaluated the clinical results of tibial condyle valgus osteotomy for severe medial osteoarthritis of the knee. The subjects were 18 patients consisting of male and 17 females. Their average age was 72.5 years, and the mean follow-up period was 3.9 years.

We evaluated the clinical results according to the JOA score, and measured FTA and \%MA on X-ray. The JOA score, FTA, and \%MA all showed significant changes after the operation.

Most of the results were satisfactory but there was one case which had severe valgus deformity of the knee one year after the operation. This case presented a strong varus deformity of the distal femur. Careful planning before operation is recommended for achieving good clinical results.
\end{abstract}

Key words : tibial condyle valgus osteotomy（脛骨顆外反骨切り術), osteoarthritis of the knee (变形 性膝関節症), clinical results（治療成績）

\section{はじめに}

中高度の内側型变形性膝関節症に対して千葉 ${ }^{2}$ ( は脛 骨顆外反骨切り術（Tibial condyle valgus osteotomy 以下 TCVO）を開発し，良好な成績が報告されてい $3^{2,5,6,9)}$. 当院でも 1997 年以来, 内側型变形性膝関 節症に対して TCVO を行っている。この論文の目的 は当院で行った症例の $X$ 線学的及び臨床成績並びに TCVO の問題点を報告する事である.

\section{手術術式および後療法}

皮切は膝蓋腱内側から遠位に約 $7 \mathrm{~cm}$ 加える. 骨切 り部の骨膜㧍よび MCL は後に下腿外反する際に十分 な範囲剥離する。骨切りは滕蓋勒帯内側付着部のやや
近位内側より開始し，外側顆間隆起の頂上を目標とし， 内側骨切りはやや下降させるように行う。内側関節面 を接触させたまま下腿を外反させ，骨切り部を開大す る。このとき関節面が開かないようにストッパーをつ けた K-wire を関節面直下に刺入しておく。イメージ 下に Mikulicz line を確認し，目標としては\%MA が 70\%前後を目指す。この位置で内側より Tプレートで 固定を行う。開大した部には腸骨より骨移植を行う。

後療法は術後 3 日目より CPM にて可動域訓練を開 始し，5 週で部分荷重を開始し，8 週間で全荷重歩行 としている。

\section{対象及び方法}

対象は 1997 年 1 月より 2001 年 1 月までに当院で内 




図 1 X線評価項目

mLDFA 並びに MPTA の計測方法 mLDFA は90 度以上で内反とし， MPTA は 85 度以下で内反とした。

（文献 8 より引用）

側型变形性膝関節症に対して TCVO を行った 29 膝の うち, 2 年以上経過観察可能であった 13 例 18 膝であ る. 性別は男性 1 例, 女性 12 例で, 手術時年齢は 66 歳 77 歳（平均 72.5 歳，術後観察期間は 2.5 年〜 6 年 (平均 3.9 年) であった。

これらの症例に対して臨床成績はJOA score で評 価し，術前之経過観察時を比較した。X線での評価は 下肢長尺片脚立位で撮影したX線で行い，大腿骨骨軸 と脛骨骨軸の交点のなす角 Femoral-tibial angle（以 下 FTA）並びに下肢機能軸（Mechanical axis 以下 MA）の膝関節通過位置を測定し，膝関節の幅を 100 \%とし内側縁を $0 \%$ ，外側縁を $100 \%$ とし\%MA を求
めた。

大腿骨のアライメントの指標として大腿骨骨頭中心 から大腿顆部中心に結んだ大腿骨機能軸と大腿骨遠位 関節面のなす角を mechanical lateral distal femoral angle（以下 mLDFA）とし，脛骨のアライメントの 指標として脛骨骨軸と脛骨近位関節面のなす角を medial proximal tibia angle (以下 MPTA) とした (図 1$)^{8)}$. mLDFA は $90^{\circ}$ 以上を内反とし, MPTA は $85^{\circ}$ 以下を反内とした。

さらに内反膝変形の骨性要素を大腿内反型 $\left(\mathrm{mLDFA}>90^{\circ}\right)$, 下腿内反型 $\left(\mathrm{MPTA}<85^{\circ}\right)$, 混合 型（mLDFA $>90^{\circ}$ かつ MPTA $<85^{\circ}$ ) にわけ，それ ぞれの JOA score を術前之経過観察時に求め, 比較 検討した。

\section{結果}

JOA score は術前 45〜65 点（平均 56.4 点）から経 過観察時 65 85 点（平均 79.1点）へ有意に改善した. FTA は術前 181 201 （平均 $187.7^{\circ}$ ） から経過観察 時 $135 \sim 173^{\circ}$ (平均 $166.6^{\circ}$ ) 一有意に減少し，\%MA は術前－70～21\%（平均－12.2\%） から経過観察時 41 150\%（平均 72.8\%）へ有意に増加した。

また内反膝の骨性要素別には大腿内反型は無く, 下 腿内反型が 8 膝, 混合型が 10 膝であった。 下腿内反 型の術前の JOA score は平均 56.2 点から経過観察時 は平均 80 点に改善し, 混合型は術前平均 57.5 点から 経過観察時 77 点に改善しており,この 2 群間に統計 学的に有意差は無かった。経過観察時に FTA が $135^{\circ}$, \%MA が 150\%と過外反となった症例が混合型の中に 含まれていた。

\section{症 例 供 覧}

症例 1.72 歳女性. 混合型の内反膝変形. FTA, \%MA，JOA score は術前 183，16\%，60 点であった が，経過観察時にはそれぞれ $165^{\circ} ， 85 \% ， 80$ 点へと 改善した（図 2 ).

症例 2.77 歳女性. 下腿内反型の内反膝変形. FTA，\%MA，JOA score は術前 $186^{\circ} ，-5 \%, 65$ 点であったが，経過観察時にはそれぞれ $173^{\circ} ， 50 \%$, 85 点へと改善した。 TCVO の当初の目標である外側 荷重とはならず矯正不足ではあるが術後 6 年経過して 疼痛無く歩行可能である (図 3 ).

症例 3.71 歳女性. 下腿内反型の内反膝変形. 




a

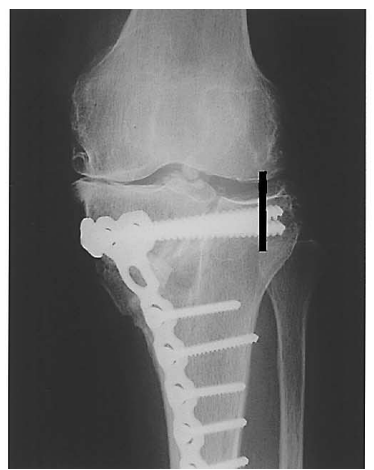

b

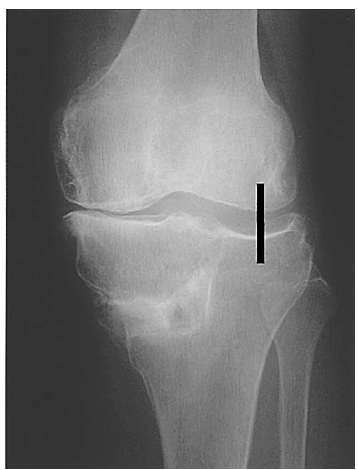

c

図 2 症例 1

$\mathrm{a}$ : 術前 FTA 183 度, \%MA16\%, JOA score 60 点

$\mathrm{b}:$ 術後

c：経過観察時（術後 3 年 8 ヶ月）FTA165 度, \%MA85\%, JOA score 80 点

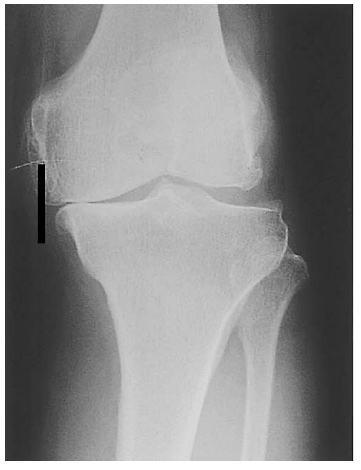

a



b

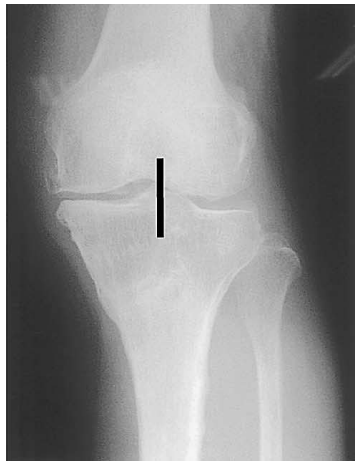

c

図 3 症例 2
a : 術前 FTA 186 度, $\% \mathrm{MA}-5 \%$, JOA score 65 点
$\mathrm{b}$ : 術後
c：経過観察時（術後 6 年) FTA173 度, \%MA50\%, JOA score 85 点

FTA，\%MA，JOA score は術前 $185^{\circ} ，-16 \%, 65$ 点であったが，経過観察時にはそれぞれ $175^{\circ} ， 41 \%$, 85 点へと改善した. 矯正不足で内側荷重であるが術 後 3 年 3 ヶ月の現在, 疼痛無く歩行可能である (図 4 ).

症例 4. 76 歳女性. 混合型の内反膝変形. FTA, \%MA, JOA score は術前 $194^{\circ},-35 \%, 60$ 点であっ たが，術後はそれぞれ $165^{\circ} ， 73 \% ， 80$ 点へと改善し た. しかし徐々に外反傾向が強くなり, 大腿骨外側顆 部の骨壊死を伴い最終経過観察時には $135^{\circ} ， 150 \%$,
70 点と著明な外反膝となり経過不良例である（図 5 ).

$$
\text { 考察 }
$$

近年内側型变形性膝関節症に対する高位脛骨骨切り 術を行う際に術前に大腿骨の形態を測定し，アライメ ント異常を考慮する方法が報告されている。 Terauchi ${ }^{7)}$ は大腿骨遠位の varus inclination が強 い症例は, HTO 後有意に再内反したと報告し, Babis ら ${ }^{1)}$ は高度内反膝に対して脛骨近位での single 


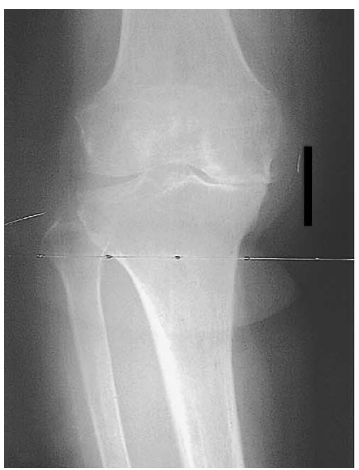

a



b

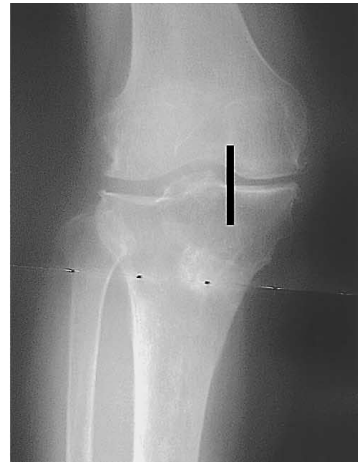

図 4 症例 3

a : 術前 FTA 185 度, $\% \mathrm{MA}-16 \%$, JOA score 65 点

$\mathrm{b}:$ 術後

c：経過観察時（術後 3 年 3 ヶ月）FTA175 度, \%MA41\%, JOA score 85 点

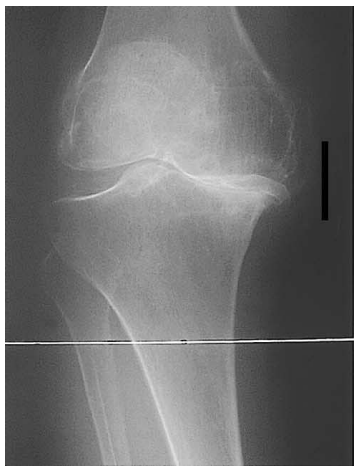

a



$\mathrm{b}$

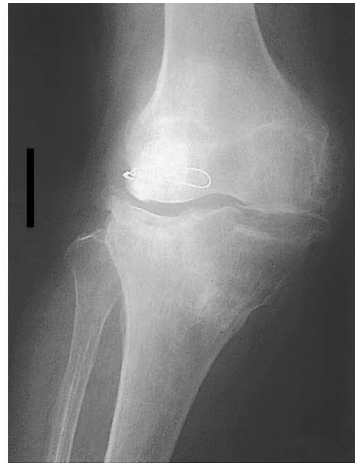

c

図 5 症例 4

a : 術前 FTA 194 度, \%MA-35\%, JOA score 60 点

b : 術後（8ヶ月） FTA 165 度, \%MA73\%, JOA score 85 点

c：経過観察時（術後 4 年 3 ヶ月） FTA135 度，\%MA150\%, JOA score 70 点 と著明な外反膝を呈した。

osteotomy では関節面の水平さが保たれない場合に は大腿骨遠位骨切りを併用する double osteotomy が 有用であると報告し, Paley ${ }^{8)}$ は脛骨骨切りは大腿骨 の malalignment が無く，脛骨が明らかに内反位の 場合が最もよい適応と報告している。

今回の調査では混合型の術後成績は下腿内反型と有 意差は無かったが，症例 4 に提示したように混合型の 症例で術後に過外反となった症例が有った。この症例
は他の症例と比較して術中や後療法で特別な变更点は なかったが，大腿骨も内反変形した内反膝に対して脛 骨のみで外側優位の荷重配分を求めてアライメントの 矯正を行うと，面接触を求めて外反した外側関節面が 点接触となる可能性があり, 渡邊ら ${ }^{9)}$ が報告したよう に外側関節面の適合性と不良となった事が，外側悪化 を助長する要因となったことが考えられる。術前に malalginment の原因がごこにあるかを十分に考慮し 
て手術の計画を立てることが良好な成績につながると 考えた。

TCVO の治療のコンセプトは近位脛骨内顆の骨切 りと下腿外反で，外側関節面の再接触と同時に外側有 意の荷重配分を得る事であるが，症例 2 や 3 で示した ように\%MA が 50\%や，41\%と矯正不足であっても それぞれ術後 6 年, 3 年経過しても臨床成績はよく, 矯正不足之予後不良は直接は結びつかない事あある. 逆に外側優位の荷重配分であっても外側関節面の適合 性が不良となった場合に症例 4 に示した様な事が起こ る場合もある．現在我々は手術を行う際には膝関節の 骨性安定性の獲得を最優先しており，外側関節面が再 接触した段階でプレート固定を行い，それ以上に下腿 を外反し\%MA を $70 \%$ 程度まで無理に矯正していな いのが実状である，当然 TCVOのコンセプトからす ると矯正不足と考えられる症例もあるが，現在のとこ ろ再内反した症例や, 内側の疼痛が改善しなかった症 例は経験していない.しかし経過観察が最長 6 年なの でより長期に経過を見る必要があると考えている.

今後の課題として, 外反矯正すると外側関節面の適 合性が悪くなり，外側関節面の適合性が良いと矯正不 足であるといった場合にどこまで外側関節面の適合性 が保たれるのか, よ゙のアライメントまで許容できるの かといった事を症例を重ねて研究することが重要であ ると考えた。

\section{ま と め}

1 ）当院で TCVO を行った 13 例，18 膝の術後成績 を報告した。
2 ）術後の成績は下腿内反型，混合型に関係なく，術 前と比較して有意に改善していた。

3 ）術後に外反变形が進行した症例ああり, 術前に malalignment の主な原因がごこにあるのか十分に 考慮して，手術の計画を立てることが良好な治療成 績に繋がると考えた。

\section{参 考 文 献}

1) Babis, C. G., et al. : Double level osteotomy of the knee : A method to retain joint-line obloquity. J. Bone Joint Surg., 84-A : 1380-1388, 2002.

2）千葉剛次 : 変形性膝関節症に対する脛骨顆外反骨切り 術. OS NOW, 13:159-166, 1994.

3）千葉剛次：中高度 OA 膝にみられる亜脱臼の高位脛骨 骨切り術による整復のメカニズム。日関外誌, $15 ： 125$ 136, 1996.

4）千葉剛次 : 脛骨顆外反骨切り術. 関節外科, $22: 730$ 741, 2003.

5）中村 智：高度内側型変形性膝関節症に対する脛骨顆 外反骨切り術の治療成績。整・災害，44：488-491, 1995.

6）寺本 司：高度变形性膝関節症に対する脛骨顆外反骨 切り術（TCVO）の臨床成績. 整・災外，49:37-41, 2000.

7) Terauchi, M., et al. : Varus inclination of the distal femur and high tibial osteotomy. J. Bone Joint Surg., 84-B : 223-226, 2002.

8) Paley, D. : Realignment for Mono-compartment Osteoarthritis of the Knee. In Principles of Deformity Correction. 479-507. Edited by Paley D, Heidelberg, Springer-Verlag, 2001

9) 渡邊 毅: 脛骨顆外反骨切り術 (Tibial Condyle Valgus Osteotomy）に打ける関節鏡所見之X線所見の 検討．整・災外，51：729-734，2002. 